\title{
GAIA SÓHAJA
}

\section{GAIA'S SIGH}

\author{
Szántó R. Tibor \\ CSc, tudományszociológus, a Magyar Felsőoktatási Akkreditációs Bizottság korábbi főtitkára \\ szantotibor01@t-online.hu
}

\section{ÖSSZEFOGLALÁS}

A (világ)járványok az emberi faj életciklusában ismétlődő események. Hatásuk fajunkra nézve nemcsak negatív, de pozitív is lehet: esélyt jelenthetnek az emberi tevékenység szükséges korrekcióira a faj túlélése érdekében. A vírusoknak az emberi fajt befolyásoló hatása talán a Gaia nagyrendszer önszabályozásaként is felfogható.

\section{ABSTRACT}

Epidemics, pandemics are recurring events in the life cycle of the human race. Their impact on our species can be not only negative but also positive: they can provide a chance for the necessary adjustments in human activities for the survival of the species. The effect of viruses on the human race may also be seen as homeostasis of the Gaia large system.

Kulcsszavak: Gaia, vírus, természet, ember, belátás, homeosztázis

Keywords: Gaia, virus, nature, man, wiseness, homeostasis

\section{SOK}

Így sóhajtott Gaia. Sok. Sok, sóhajtották a fák, a füvek, mind a növények, állatok. A vizek, folyók, tavak, tengerek. Az ér és az óceán. A levegő is így sóhajtott: sok. Nem bírjuk. Nem bírjuk a terhelést, a nyakló nélkül fokozódó igénybevételt, a semmibevételt. A felelőtlenséget, a zárójelezést. Sok.

Mindig is így volt? Sosem volt az ember tekintettel élettelen és élő környezetére? Mindig is felelőtlen volt? Elvette, ami kellett neki, amiről úgy gondolta, hogy kell neki. Vagy mégsem? Lett volna, valóban, valami aranykor-féle, amikor csak annyit vett el, amennyi tényleg kellett? Amikor volt még valami harmónia? Belátás? Amikor az ember még tisztelte a fákat, a füveket, a növényeket, az állatokat? Akkor is, ha ki kellett vágnia, letépnie, leölnie? Hogy saját túlélését biztosítsa. 
Nyolcmilliárd ember (URL1). Sosem élt még ennyi a Földön. Igen, az a 8 milliárd ember is Gaia. Lovelock-Gaia (Lovelock, 1972; Lovelock-Margulis, 1974). A nagy rendszer része. Mondhatjuk, benne van a teljes programban. Igen, ez az egész talán benne van a(z evolúciós?) programban (történésben, változásban, nevezzük bárhogy), így, ahogy történik, nyolcmilliárdostul, szennyezésestül, semmibevételestül, felelőtlenségestül. Járványostul. Akár adott előre az egész „,program”, teleologikusan, akár nem úgy, csak így alakult, így történik, véletlenszerüen, meg esetenkénti alkalmazkodásokkal. (Talán a felelőtlenség is lehet egyfajta alkalmazkodás?) Az eredmény szempontjából mindegy. Nyolcmilliárd. Sok. Sok ennyi ember, sok, amit bevisznek, sok, amit kibocsátanak. Sok, amit csinálnak, sok, ahogy csinálják. Sok, ahogy csináljuk. A gázok, a müanyagok, a szemét. A felélés, a szennyezés, a beavatkozás. Sok.

Ezért sóhajt most Gaia. Most is sóhajt. Sóhajtott már korábban is, akkor még kevesebb ember élt a Földön, mégis sóhajtania kellett. Többször is. Mintegy önszabályozásként. Mert akkor, régebben, az adott kor termelési-technikai-higiéniai-környezeti eltartó képességéhez képest a mostaninál kevesebb ember, a mostaninál kevesebb szennyezés is lehetett sok. S olyankor jött valami járvány vagy háború, átrendeződés, éghajlatváltozás. Pusztulás, tisztulás. Valami, ami ha drasztikus volt is, felkavarta a viszonyokat, a tevékenységeket. Sebeket okozott, alkalmasint elég komolyakat, de aztán a sebeken át, a romokon tisztultabban lehetett folytatni. Vagy újrakezdeni. Mert hát az ember már csak ilyen, úgy tủnik, tényleg ez van a programban. Az emberiben és a nagyrendszer Gaiában. (Mi a vége? Önmegsemmisítés? Az ember nélküli Gaia? Vagy nincs vége? Sosincs vége, mindig csak kezdjük újra? De hát mennyit, tízmilliárd embert is elbírna a Föld-Gaia?)

Gaia most is sóhajt, úgy látszik. Egyelöre (2020. március 10-én, amikor e mondatot írom) még kicsinek látszik a sóhaj (113 702 fertőzött, 4012 halott, URL2), legalábbis nem olyan vészesen nagynak az emberéletek tekintetében, kivált a 8 milliárdhoz képest, de lehet, hogy nagyobb lesz ez a sóhaj (2021. november közepén már 253 millió a nyilvántartott fertőzött és 5,1 millió a halott, az aktuális napi adatok elérhetők itt: URL3), akár jóval nagyobb is, mint gondolnánk, e tekintetben is. A 8 milliárdhoz viszonyítható. Releváns. Ahogy a természeti erőforrások, kivált az olajfelhasználás vonatkozásában, meg a távolsági közlekedésben, s a levegő tisztaságában is releváns, sok helyütt már számottevő, itt pozitív irányban. Mert Gaia csak így tud segíteni magán, ha már ember része nem segít, nem gondol előre, nem változtat semmit, marad felelőtlen, tekintet nélküli. Belátás nélküli.

Talán, valóban, rosszul csináljuk, és még túl sokan is vagyunk? Mihez képest? A javak elosztásának gyorsulóan igazságtalan voltához képest, az ebből fakadó tömeges elnyomorodáshoz képest, s Föld-Gaia mostani eltartóképességéhez, megújulási képességéhez képest. 


\section{ESÉLY}

Ez egy esély. Egy esély is lehet. Hogy kilábaljunk. Nem a vírusból, nem elsősorban abból. A világhelyzetünkből. Abból. Esély arra, hogy végre belássuk, nem mehetnek úgy a dolgok tovább, ahogy eddig mentek. Vagyis, hogy mehetnek, de akkor annak az önfelszámolás a vége. Ha így megy tovább, akkor annyi más faj után magunkat is kipusztítjuk. Talán már nem is olyan sokára.

Ökológiai és humánválságok. Harminckét éve írtam ezzel a címmel egy cikket egy napilapba (Magyar Nemzet, 1989. december 18. Emberkép melléklet). Ez volt az első bekezdése:

„A jól ismert világméretü ökológiai problémák egyre észrevehetőbben perzselik talpunkat. (Levegö-, víz-, talajszennyezés, ózonlyuk, szénhidrogének, kemikáliák, folyók, tavak, fajok és erdők pusztulása, sivatagosodás és pocsolyásodás, saját létfeltételeink rövidlátó megsemmisítése.) A helyzet kezd kényelmetlenné válni, elszaladni azonban nem tudunk. Nincs hova. Szennyünk árnyékként követ minket, hozzánk tartozik. Bárhová megyünk, mindenhol újratermeljük. S már amúgy sincs nagyon hova menni. Mindenhol ott vagyunk. Nézők és szereplők egy személyben. Furcsa színjáték. Hóhérok és akasztottak. Mintha a természet saját magunkkal hajtatná végre rajtunk a halálos ítéletet. Ítéletünket. Ennyire botor volna az ember? Vagy csupán arról van szó, hogy ez van a programban, slussz-passz?"

Mi változott az elmúlt három évtizedben? A horizont. Harminckét évvel közelebb vagyunk. Mihez? A véghez? Vagy a végre valóban kijózanító, cselekvésgeneráló felismeréshez? Nemcsak az elhatározáshoz, hanem a tettekhez is? Egyénenként, csoportosan, országosan, globálisan? Vagy még mindig túl sok az ellenérdek és a rövidlátás? Miért adjak le az igényeimből, a megszokott kényelmemből, a jólétemből? Miért mondjak le az igényeim küszöbönálló kielégítésérôl, a végre beköszöntő kényelmemröl, a csak most eljövő jólétemről? Miért pont én, Kínában, Indiában vagy máshol élve, Magyarországon, aki éppen most kezdhetném élvezni azt, amit sokan mások más országokban már több évtizede élveznek?

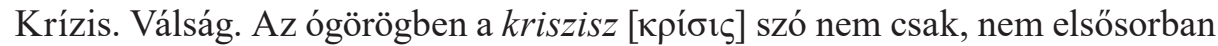
válságot jelentett. Elválasztás, megkülönböztetés. Választás, kiválasztás, eldöntés. Kimenetel. Vád, per, elítélés, bírálás, kárhoztatás. Ítélet. Értelmezés, magyarázat, válópont, válság. Rajtunk áll, hogy erre a mostani, immár több évtizede alakuló, húzódó válságra melyik jelentés lesz igazán érvényes. Mi értelmezzük, mi döntjük el, mi választunk. Mi fogjuk perbe magunkat, mi bírálunk, s mi hozzuk meg az ítéletet is. A saját magunkra (is) vonatkozó ítéletet. Aztán majd mi magyarázzuk. Ha lesz még magyarázat. Ha lesz még mi... 


\section{MOST}

Most még van mi. És van magyarázat. Tudjuk. Tudjuk, hogy nem jól van, hogy nem folytatható vég nélkül a természetfelélés, természetölés, az erőforrások zsigerelése, kimerítése. A szennyezés. A távolságtalan távolságok, az ide-oda röpködés, a mindegy hova kiszervezés, csak olcsóbb legyen, a mindegy milyen módon, csak a profit nőjön. A végtelen gazdagodás, a végtelen szegényedés. A már régen nem emberi emberi kapcsolatok. A kütyük és az újabb, mindig a legújabb kütyük. A globális világrendetlenség. Mit tehetünk? Ne ezt kérdezd. Mit tehetek én? - ezt kérdezd. Mit kell másképp csinálnom, mint eddig? Mit, min változtassak? Ezt kérdezd. Mert valószínúleg csak így fog menni. „Alulról” vagy alulról is, és csak akkor, ha mind többen elkezdjük. Ha nagyon sokan elkezdjük, még többen folytatjuk, és nem is hagyjuk abba.

Mit, hogyan? Először hozzáállást, alapállást változtass. A belsővel kezdd. A belsőddel. A Biblia szerint. Vagy a Korán szerint. Vagy a Talmud szerint. Vagy Konfuciusz, Lao-ce, Szókratész vagy Buddha szerint. A józan eszed és a romlatlan, egész lelked szerint. Hagyj fel a tudat, a gondolkodás, az érzelmek, a viszonyulások tökéletlenségeivel. Fukarság, becstelen sóvárgás, rosszindulat, harag, gyülölködés, kíméletlenség, irigység, szemfényvesztés, csalás, makacsság, versengés, önhittség, gőg, hiúság, hanyagság. Hagyj fel velük! Minddel és minden hasonlóval. Igen, a versengéssel is, ahogy a Buddha tanította az elöbbiek szerint, meg ahogy Pál apostol írta a Filippibeliekhez: „Semmit nem cselekedvén versengésből, sem hiábavaló dicsőségből, hanem alázatosan egymást különbeknek tartván magatoknál. Ne nézze kiki a maga hasznát, hanem mindenki a másokét is.” (Filipp. 2:3-4.) A Korán prófétai tömörségü szavaival: „A halmozási versengés eltérít." (102:1.) Bármit is halmozol, bármiért is versengsz másokkal szemben. Anyagi javak, pénz, hatalom, befolyás, természeturalom, mindegy. Eltérítenek, elvakítanak. Elvonnak attól, ami igazán fontos. „Kiviszik az embert a világból”, ahogy a talmudi tanítás mondja. S meglehet, nemcsak átvitt értelemben, de szó szerint is kivisznek. Mindannyiunkat.

Hagyj fel tehát a versengéssel! Meg a kényelmes nem gondolkodással, a reklámoknak és politikusoknak bedőléssel, az ,influencerek” követésével. Magadat kövesd, a józan eszednek higgy, a romlatlan lelked útmutatását kövesd. Hagyj fel a szennyezéssel, az újabb és újabb kütyük megvásárlásával, a világ másik végébe utazással, a több ezer személyes óceánjáróra befizetéssel. Fordulj a közelebbi világ, a környezeted, a szeretteid, a barátaid, az embertársaid felé. A felebarátaid felé, ahogy az írások mondják. Nem kell messzire menni.

És nem, nem attól leszel több, ha többed van, ha anyagilag, fizikailag van többed, pénzben, autóban, házban, nyaralóban, kütyüben. Nem. Belül legyél több. Ezzel kezdd. 
S a folytatás? Az már szinte magától jön. Ha sokan, nagyon sokan elkezdjük, és még többen folytatjuk. Akkor nem lesz szükség a távolságtalan távolságokra, a kiszervezésre, a kizsigerelésre, a szennyezésre. A vég nélküli növekedésre. Akkor talán a végtelen gazdagodásnak és a végtelen szegényedésnek is vége szakad, vagy legalábbis mindkettő mérséklődik, akár jelentősen. S akkor talán lesz még nemcsak magyarázat, de lesz még „mi”.

\section{KATONA}

Ha nincs katona, nincs háború. Ha nincs katona, nincs háború? Ilyen egyszerü volna, valóban? Változás, egyénileg, belsőleg, sokan? Az érdekek, a felturbózott és vélt szükségletek világában? Illúzió. Ez az egész illúzió, szép vágyálom, utópia. Intellektuális hübrisz. Meglehet, tényleg az. S talán remény. Halvány remény, hogy lesz még harminc évünk, még egy emberöltő, ami alatt felnő egy új generáció. Új menedzserek, új vezetők, új politikusok. Új emberek. S talán ők már nem rontják el. S talán azok az emberek, vezetők, politikusok már máshogy müködnek majd, nemcsak ,alulról”, de „felülről” is felelősen, tevőlegesen. Példával, szabályozással.

Elherdált jelen, elherdált jövő, vagy remény, halvány remény. Mert esélyünk, azt hiszem, nincs más. Hacsak Gaia meg nem teszi velünk, helyettünk...

Születés, élet, halál. Egyed- és törzsfejlődés. Ez a fajok útja. Miért lenne az emberi faj kivétel? Nem isteni végítélet lesz, hanem a folyamatokból következő evolúciós fejlemény. Akár programozott, akár nem. De ha így is lesz, rajtunk áll, hogy mikor. Előbb vagy később?

\section{TUDOMÁNY}

Mit mond a tudomány, milyen vonatkozó eredményekre jutottak a kutatók? „Objektíven”, elfogulatlanul, de az élővilág és benne saját emberi sorsunk iránt szükségképpen mégiscsak elfogultan.

„Noha a valaha élt fajoknak talán csak 2\%-a él ma, a fajok abszolút száma nagyobb, mint valaha. Mi, emberek egy ilyen biológiailag sokszínű világban fejlődtünk ki, és egy ilyen világot pusztítunk éppen el. [...] Napjainkban a fajok kihalási aránya több százszor vagy ezerszer gyorsabb, mint az elmúlt néhány tízmillió évben uralkodó »normál«, más szóval »háttér« arány. [...] Több mint négyszáz gerinces faj halt ki az elmúlt száz évben, ez a kihalás az evolúció normális lefolyása esetén akár tízezer évet is igénybe vett volna. [...] A növekvő emberi populáció, a növekvő fogyasztás és a jövőbeni növekedés felgyorsíthatja a fajok rohamos eltünését, amely a mai folyamból rohanó áradattá válhat - a túlélés ezen problémáját 
csak az emberek képesek enyhíteni. [...] A kihalási válság, akárcsak a mérgezési és éghajlati válság, amelyhez kötődik, egzisztenciális fenyegetést jelent a civilizáció számára. [...] Van még idő, de a lehetőségek ablaka már majdnem bezárult. Meg kell mentenünk, amit tudunk, vagy örökre elveszítjük ennek lehetőségét. Nem kétséges például, hogy több világjárvány is lesz, ha folytatjuk az élőhelyek pusztítását és a vadon élő állatok emberi fogyasztásra szánt élelmiszerként és hagyományos gyógyszerként való kereskedelmét. Ez olyasvalami, amit az emberiség nem engedhet meg magának, mivel ez a civilizáció összeomlásához vezető fordulópont lehet. A tét az emberiség és a legtöbb élő faj sorsa. A jövő generációi jobbat érdemelnek tölünk." (Ceballos et al., 2020) ${ }^{1}$

Egy következő, át- és előretekintő cikk szerzőgárdája széles szakirodalmi bázison még határozottabban fogalmaz:

„...a jövőbeni környezeti feltételek sokkal veszélyesebbek lesznek, mint azt jelenleg gondolják. A bioszférát és annak összes életformáját - beleértve az emberiséget is - fenyegető veszélyek mértéke valójában olyan nagy, hogy azt még a jól tájékozott szakértők számára is nehéz felfogni. [...] A helyzet súlyossága alapvető változtatásokat követel meg a globális kapitalizmusban, az oktatásban, $\mathrm{s}$ az egyenlöséget illetően, amelyek magukban foglalják többek között az örökös gazdasági növekedés eltörlését, az externáliák megfelelő árazását, a fosszilis tüzelőanyag-használatból való gyors kilépést, a piacok és a tulajdonszerzés szigorú szabályozását, a vállalati lobbizás uralását, valamint a nők szerepvállalását. Ezek a döntések szükségképpen nehéz megbeszéléseket fognak maguk után vonni a népességnövekedésről és a csökkenő, de igazságosabb életszínvonal szükségességéről. [...] Tekintettel arra, hogy létezik egy emberi »optimista elfogultság«, ez

1 „Even though only an estimated $2 \%$ of all of the species that ever lived are alive today, the absolute number of species is greater now than ever before. It was into such a biologically diverse world that we humans evolved, and such a world that we are destroying. [...]

Today, species extinction rates are hundreds or thousands of times faster than the »normal« or »background « rates prevailing in the last tens of millions of years. [...]

More than 400 vertebrate species became extinct in the last $100 \mathrm{y}$, extinctions that would have taken up to $10,000 \mathrm{y}$ in the normal course of evolution. [...]

The growing human population, increasing rates of consumption, and projected growth in the future can only accelerate the rapid disappearance of species, now a stream, to a rushing torrent-a problem for survival that only human beings have the power to alleviate. [...]

The extinction crisis, like the toxification and climate crises to which it is tied, poses an existential threat to civilization. [...]

There is time, but the window of opportunity is almost closed. We must save what we can, or lose the opportunity to do so forever. There is no doubt, for example, that there will be more pandemics if we continue destroying habitats and trading wildlife for human consumption as food and traditional medicines. It is something that humanity cannot permit, as it may be a tipping point for the collapse of civilization. What is at stake is the fate of humanity and most living species. Future generations deserve better from us." 
arra késztet egyeseket, hogy alábecsüljék a válság súlyosságát, és figyelmen kívül hagyják a szakértői figyelmeztetéseket. Egy jó kommunikációs stratégiának ideális esetben anélkül kell semlegesítenie ezt az elfogultságot, hogy aránytalan félelmet és kétségbeesést váltana ki [...]. Ezért a bioszféra jövőjével és az emberi jóléttel foglalkozó szakterületek szakértőinek kötelessége, hogy ne hallgassanak el semmit, kerüljék az előttünk álló hatalmas kihívások cukormázzal való elfedését, és »az igazat mondják, úgy, ahogy van«. Minden más a legjobb esetben is félrevezetö, illetve felületes és a legrosszabb esetben akár halálos is lehet az emberiség számára." (Bradshaw et al., 2021)²

$\mathrm{S}$ ha a Gaia-hipotézis kiterjesztése nem teljes örültség? Ha az ember tevékenysége mindenestől része a nagy egésznek, a „programnak”, az evolúciónak, az időbeli kifejletnek, nevezzük bárhogyan is, $\mathrm{s}$ hasson bárhogyan is az élő és élettelen környezetre, a bioszférára, Föld-Gaiára s az emberre magára? Akkor nincs mit tenni, ez van, és kész? Akkor a mégoly tisztán látó és elhivatott, ámde az egészhez, a 8 milliárdhoz képest maroknyi ember mit tehet? Ezért kéne, hogy ne maroknyian, de sokan legyünk. Belátók, önmérséklők, nem versengők, együttmüködők. Sokan. Nagyon-nagyon sokan. Mert mindannyian felelősek vagyunk. Igen, minden egyes ember felelös.

„Hacsak nem történik globális katasztrófa - egy meteorit becsapódása, világháború vagy világjárvány -, az emberiség még sok évezredig jelentős környezeti erő marad." (Crutzen, 2002) ${ }^{3}$

Lesz-e olyan erős a Covid19 pandémia, hogy az embert belátásra, önmérsékletre bírja? Hogy ne vigyük ki magunkat a világból, s legyen még számunkra (is) néhány ezredév.

${ }^{2}, \ldots$ future environmental conditions will be far more dangerous than currently believed. The scale of the threats to the biosphere and all its lifeforms - including humanity - is in fact so great that it is difficult to grasp for even well-informed experts. [...]

The gravity of the situation requires fundamental changes to global capitalism, education, and equality, which include inter alia the abolition of perpetual economic growth, properly pricing externalities, a rapid exit from fossil-fuel use, strict regulation of markets and property acquisition, reigning in corporate lobbying, and the empowerment of women. These choices will necessarily entail difficult conversations about population growth and the necessity of dwindling but more equitable standards of living. [...]

Given the existence of a human »optimism bias« that triggers some to underestimate the severity of a crisis and ignore expert warnings, a good communication strategy must ideally undercut this bias without inducing disproportionate feelings of fear and despair [...]. It is therefore incumbent on experts in any discipline that deals with the future of the biosphere and human well-being to eschew reticence, avoid sugar-coating the overwhelming challenges ahead and »tell it like it is." Anything else is misleading at best, or negligent and potentially lethal for the human enterprise at worst."

3 „Unless there is a global catastrophe - a meteorite impact, a world war or a pandemic mankind will remain a major environmental force for many millennia." (A szerző fordításai.) 
Vagy ez a járvány nem számít, s a megviselt bioszférára, életfeltételeinkre, a biodiverzitásra áttételesen, az ember korlátozásával nemcsak pozitívan, de negatívan is hat? (Bang-Khadakkar, 2020) Nem tud a javunkra válni, belátásra, önmérsékletre bírni? Mert valóban, ez van a „programban”?

A vírusoknak ,az ökológiai egyensúly fenntartásában fontos szerepük van, mert sikeres terjedésükhöz feltétlenül kell a nagyszámú fogékony gazda. Így »nagy pusztítást « csak akkor tudnak végezni, ha a fogékony populáció sürüsége egy kritikus értéket meghalad, ekkor viszont hatékonyan csökkenthetik egy-egy járvánnyal a gazdák létszámát” (Koch, 1998).

A vírusok az evolúció kamikazéi. Megölik a megtámadott szervezetet, s azzal együtt ők maguk, a támadó egyedek is elpusztulnak. Ez van? Létszámcsökkenés az emberi populációban, csökkenés a szennyezésben, aztán megy tovább minden, mintha mi sem történt volna?

Talán ez is a Gaia-homeosztázis része. Az ember által okozott zavarok enyhítése, kiegyenlítése. Talán nem program van, hanem alkalmazkodás. Nem elöre rögzített program, nem teleológia. Nem célirányosság, hanem célszerüség. Alkalmazkodás, homeosztázis. Nemcsak az atmoszféra, de az élővilág, s az önmagukban nem egészen élők, a vírusok is ezt szolgálhatják, az önszabályozást. Ezt is. Azok is a nagyrendszer Gaia. Velük, általuk sóhajt most Gaia. Talán a mi érdekünkben?

\section{IRODALOM}

Bang, A. - Khadakkar, S. (2020): Biodiversity Conservation during a Global Crisis: Consequences and the Way Forward. Proceedings of the National Academy of Sciences of the USA, 117, 48, 29995-29999. DOI: 10.1073/pnas.2021460117, https://www.pnas.org/content $/ 117 / 48 / 29995$

Bradshaw, C. J. A. et al. (2021): Underestimating the Challenges of Avoiding a Ghastly Future. Frontiers in Conservation Science, 13 January 2021. DOI: 10.3389/fcosc.2020.615419, https:// www.frontiersin.org/articles/10.3389/fcosc.2020.615419/full

Ceballos, G. - Ehrlich, P. R. - Raven, P. H. (2020): Vertebrates on the Brink as Indicators of Biological Annihilation and the Sixth Mass Extinction. Proceedings of the National Academy of Sciences of the USA, 117, 24, 13596-13602. DOI: 10.1073/pnas.1922686117, https://www.pnas. org/content/117/24/13596

Crutzen, P. J. (2002): Geology of Mankind. Nature, 415, 23. DOI: 10.1038/415023a, https://www. nature.com/articles/415023a

Koch S. (1998): Szubjektív virológia. 8. rész, Hogyan „kórokoz” a vírus? Természet Világa, 10, https://www.termvil.hu/archiv/tv98/tv9810/korok.html. Újraközölve in: Juhász-Nagy S. Nienhaus R. - Szilágyi A. (szerk.): Pillanat Ember Végtelenség. Írások Koch Sándortól és Koch Sándorról. Budapest: Scientia Kiadó, 2005, 89.

Lovelock, J. E. (1972): Gaia as Seen through the Atmosphere. In: Westbroek, P. - deJong, E. W. (eds.): Biomineralization and Biological Metal Accumulation. Reidel, 1983. 15-25. http://www. jameslovelock.org/gaia-as-seen-through-the-atmosphere/ 
Lovelock, J. E. - Margulis, L. (1974): Atmospheric Homeostasis by and for the Biosphere: The Gaia Hypothesis. Tellus, 26, 1-2, 2-10. DOI: 10.3402/tellusa.v26i1-2.9731, https://www.tandfonline.com/doi/pdf/10.3402/tellusa.v26i1-2.9731?needAccess $=$ true

URL1: https://www.worldometers.info/world-population

URL2: https://www.who.int/docs/default-source/coronaviruse/situation-reports/20200310-sitrep50-covid-19.pdf?sfvrsn $=55 \mathrm{e} 904 \mathrm{fb} \_2$

URL3: https://coronavirus.jhu.edu/ 